\title{
STRATEGI GURU MADRASAH MENINGKATKAN MUTU PEMBELAJARAN ERA DISRUPSI DI KEDIRI
}

\author{
Dhendi Pristian*, Muh. Hambali** \\ Universitas Islam Negeri Maulana Malik Ibrahim Malang, Indonesia \\ Email: dhendipristian@yahoo.com, hambali@pai.uin-malang.ac.id
}

\begin{abstract}
Learning quality is the determinant of service in a madrasa. The teacher who has an educational position, instilling values that uphold civilization does not merely transfer knowledge from the teacher to students in the classroom. In this disruption era, artificial intelligence emerged which replaced the teacher's position in the matter of transferring knowledge. The condition of information technology innovation continues to experience rapid development in the era of industrial revolution 4.0. The impact is that teachers need mastery of pedagogy based on the use of strategies and online learning resources. This article will describe and analyze the model of planning, implementation and strategy of madrasah teachers to improve the quality of graduates in MAN 1 and MAN 2 Kota Kediri with a qualitative approach, while the type of case study research with a multicasus study design. Research Results in these two madrasas are: First, the concept of planning is a). create teamwork and choose needs according to the vision and mission, b). invite speakers of outstanding teachers, c). design meaningful learning that is short term, long term according to the vision, mission and objectives of the madrasa, d). make programs and determine policies, e). recheck and revise planning. Second, the steps of Implementation are: a). Commitment, b). teamwork, c). Communication, d) Implementation of programs is 1). improving the quality of mix-based subject teachers, 2). improving the quality of learning, 3). improving service quality and curriculum development, 4). increase in academic and non academic achievements.
\end{abstract}

Keywords : Strategy; Teacher of Madrasah; Graduate Quality and Era disruption

Abstrak. Mutu pembelajaran menjadi penentu layanan jasa di sebuah madrasah. Gurulah yang mempunyai kedudukan mendidik, menanamkan nilai-nilai yang menjunjung tinggi keadaban tidak sekedar memindahkan pengetahuan dari guru ke peserta didik di ruang kelas. Era disrupsi ini, kecerdasan buatan bermunculan yang menggantikan posisi guru dalam persoalan memindahkan pengetahuan. Kondisi inovasi teknologi informasi terus-menerus mengalami perkembangan pesat pada era revolusi industri 4.0. Dampaknya guru membutuhkan penguasaan pedagogi yang berbasis penggunaan strategi dan sumber pembelajaran daring. Artikel ini akan mendiskripsikan dan menganalisis model perencanaan, implementasi dan strategi guru madrasah meningkatkan mutu lulusan di MAN 1 dan MAN 2 Kota Kediri dengan pendekatan kualitatif, adapun jenis penelitian studi kasus dengan rancangan penelitian multikasus. Hasil Penelitian di dua madrasah ini adalah : Pertama, konsep perencanaan adalah a). membuat teamwork dan memilih kebutuhan sesuai visi dan misi, b). mengundang narasumber guru yang berprestasi, c). merancang pembelajaran bermakna yang jangka pendek, jangka pangjang sesuai visi, misi dan tujuan madrasah, d). membuat program dan menentukan kebijakan, e). mengecek ulang dan merevisi perencanaan. Kedua, langkah-langkah Implementasi adalah : a). Komitmen, b). teamwork, c). Komunikasi, d) Implementasi program-program adalah 1). peningkatan kualitas guru mata pelajaran berbasis bauran, 2). peningkatan mutu pembelajaran, 3). peningkatan kualitas pelayanan dan pengembangan kurikulum, 4). peningkatan prestasi akademik dan non akademik.

Kata Kunci : Strategi; Guru Madrasah; Mutu Lulusan; Era disrupsi. 


\section{PENDAHULUAN}

Pendidikan mempunyai tanggung jawab besar dalam menyiapkan sumber daya manusia guna membekali masa depan generasi penerus bangsa. Madrasah adalah salah satu institusi pembelajaran yang mempunyai guru harus dapat meningkatkan kompetensi pedagogi dalam mendesain pembelajaran yang relevan dengan kebutuhan era industri 4.0. Era ini ditandai perkembangan teknologi yang berlangsung secara evolutif. Kecanggihan teknologi telah memberikan harapan baru karena memberikan banyak kemudahan dalam mengakses berbagai sumber informasi yang bersifat daring. Apalagi peserta didik merupakan generasi Z saat ini, ia sebagai pribumi digital yang telah akrab dengan properti HP smartphone terkoneksi dengan internet.

Hal ini berdampak terhadap gaya belajar dan literasinya cepat memecahkan masalah lebih praktis yang disajikan secara daring. Mereka enggan meluangkan proses panjang untuk mencermati suatu masalah. Oleh sebab itu, seorang guru sebaiknya perlu mendidik anak tentang konsep proses, daya tahan, dan komitmen dalam menyelesaikan masalah. Sementara itu, para guru lebih banyak lahir 1960-1970 merupakan generasi X. Generasi ini dilahirkan dengan keterbatasan teknologi yang tidak sepesat sekarang sehingga guru menghadapi gaya literasi dan pola belajar peserta didik mengalami disrupsi, dikarenakan gurunya lebih menyukai sumber ilmu pengetahun dan cara belajar yang disajikan secara luring. Mutu pembelajaran artinya memiliki proses yang baik dalam kegiatan belajar mengajar sehingga melahirkan output berkompeten yang sesuai dengan kebutuhan di dunia sekarang ini, sehingga mampu membangun bangsa dan bersaing di era disrusi.

Era disrupsi memberi dampak yang cukup luas dalam berbagai aspek kehidupan, termasuk tuntutan dalam inovasi pembelajaran yang tidak sebatas mengedepankan tatap muka, namun butuh ditunjang fasilitas sumber online di setiap pembelajaran. Model pembelajaran merupakan modal adanya inovasi pendidikan. Pendidikan adalah kunci dari maju atau mundurnya suatu bangsa dan negara karena di tangan pendidikan yang bermutulah generasi bangsa di bentuk untuk memiliki kompetensi (Lyle, 1993). Dengan demikian, Pendidikan yang bermutu adalah kunci dari majunya suatu negara. Seperti halnya Negara Findlandia menjadi negara maju karena memilih sektor pendidikan untuk membangun sumberdaya manusia yang cerdas dan berkompeten.

Pendidikan secara umum dipahami sebagai proses pendewasaan sosial manusia menuju pada tingkatan yang semestinya, yaitu terbentuknya manusia seutuhnya, meliputi keseimbangan aspek-aspek kamanusiaan yang selaras dan serasi baik lahir dan batin. Di dalamnya mengandung arti yang berkaitan dengan tujuan memelihara dan mengembangkan fitrah serta potensi menuju insan kamil (Lachlan E.D, 2006).

Untuk mencapai kualitas pendidikan, salah satu faktor adalah bagaimana langkah seorang guru menggunakan model pendekatan pembelajaran untuk menempatkan proses sehingga mencapai hasil akhir yang bermakna. Dengan strategi yang terarah dan diaktualisasikan dengan baik maka hasilnya adalah out put yang dibentuk akan sangat berkompenten sesuai apa yang sudah di targetkan. Untuk mencetak hasil akhir dari suatu proses pembelajaran maka saling berkaitan dengan komponen-komponen satu dengan yang lainya. Untuk mendapatkan hasil yang bermutu maka harus terhindar dari kesalahan sekecil apapun (Lachlan E.D, 2006).

Keberhasilan madrasah sangat ditentukan oleh guru dalam menciptakan model pembelajaran untuk mencapai hasil yang optimal. Sehingga pada akhirnya akan berdampak pada tercapainya tujuan lembaga pendidikan dan perubahan yang diharapkan pada peserta didik. Hal ini searah dengan pendapat dari Muh. Hambali (JMPI, 2016) bahwa setiap guru mempunyai tanggung jawab sebagai pendidik yang profesional yang membekali dasar-dasar kepribadian peserta didik. Kepribadian peserta didik akan menentukan ketahanan belajar dan kreatifitas membentuk jadi diri peserta didik. Sejatinya kepribadian guru dapat menginspirasi perilaku para peserta didik di madrasah (who is behind the school) (El Mulyasa, 2011). Berbagai riset juga telah membuktikan bahwa faktor karakteristik pemimpin seorang guru menjadi model dan panutan di sebuah madrasah.

Guru mempunyai tanggung jawab di kelas sebagai kompetensi kepemimpinan yang akan menentukan subtansi pembelajaran dan membekali kepribadian yang meningkatkan cara belajar lebih baik dari sebelumnya. Dalam Al-Qur"an dan Al-Hadits banyak membahas tentang kepemimpinan, seperti pada surat Al-An"am ayat 165: 
"Dan Dia lah yang menjadikan kamu penguasa-penguasa di bumi dan Dia meninggikan sebahagian kamu atas sebahagian (yang lain) beberapa derajat, untuk mengujimu tentang apa yang diberikan-Nya kepadamu. Sesungguhnya Tuhanmu Amat cepat siksaan-Nya dan Sesungguhnya Dia Maha Pengampun lagi Maha Penyayang (QS.Al-An'am:165)."

Quraish Shihab dalam menafsirkan surat Al-An'ām ayat 165, beliau antara lain mengemukakan kesimpulan setelah memperhatikan konteks ayat-ayat yang menggunakan kedua bentuk jamak itu bahwa bila kata khulafā` digunakan Al Qur`ān, maka itu mengesankan adanya makna kekuasaan politik dalam mengelola satu wilayah, sedang bila menggunakan bentuk jamak khalā 'if, maka kekuasaan wilayah tidak termasuk dalam maknanya. Ayat tersebut menjelaskan bahwa pemimpin memunyai nilai tanggung jawab profesi. Profesi guru tentunya menyangkut pembelajaran di kelas yang membutuhkan kontektualisasi agar relevan dengan zaman. Tugas guru adalah demikian, yaitu menterjemahkan setiap zaman agar dapat bersahabat dengan anak-anak. Tuntutan Islam lebih universal bahwa kepemimpinan itu lebih spesifik lagi kepada setiap manusia yang hidup terlahir sebagai pemimpin, baik memimpin dirinya maupun kelompoknya. Dengan demikian kepemimpinan dalam ajaran Islam dimulai dari setiap individu. Setiap orang harus bisa memimpin dirinya dari taqarrub kepada Allah dan menjahui larangan-Nya. Apabila manusia sudah bisa memimpin dirinya, maka tidak mustahil ia akan lebih mudah untuk memimpin orang lain. Disamping itu pertanggungjawaban pemimpin dalam konteks Islam tidak serta merta hanya kepada sesama manusia, tetapi yang paling utama adalah pertanggung jawaban kepada Khaliknya.

Seorang guru membutukan kompetensi kepemimpinan dan penguasaan bidang teknologi agar dapat memimpin di kelas. Ini artinya seorang guru memiliki cara mengajarkan materi dan dapat mengembangkan keteladanan sebagai sumber rujukan keseharian peserta didik baik di rumah ataupun di lingkungan madrasah, sehingga mampu membawa unsur-unsur lembaga secara sistemik ke arah yang diinginkan sesuai dengan harapan yang telah dikembangkan di silabus dan RPP. Kompetensi pedagogi merupakan dasar pengetahuan dan dasar keterampilan yang perlu dikuasai oleh para guru agar mampu beradaptasi dengan perkembangan teknologi informasi. Perkembangan ini ditandai oleh setiap orang,termasuk peserta didik sehari-harinya baik komunkasi, sumber belajar dan cara memenuhi kebutuhan sehari-hari menggunakan smartphone yang terkoneksi dengan internet. Pola hidup seperti ini tidak bisa terhindarkan karena setiap kebaruan teknologi menawarkan kemudahan, kecepatan dan efektivitas. Namun, apabila ini tidak ditunjang kesadaran penggunaan teknologi berdampak negatif dalam menggunakan fasilitas tersebut. Tugas guru bukan sekedar memindahkan ilmu pengetahun kepada peserta didik, jika ini penjelasan dapat diambil oleh aplikasi teknologi atau kecerdasan buatan (robot). Tugas lebih mulai lagi menanamkan nilai, sejarah keteladan, dan akidah akhlak. Tugas-tugas membutuhkan internalisasi sebagai pribadi yang ikhlas dan unggul sehingga menyebabkan tercipta pembelajaran yang melahirkan prestasi.

Keberhasilan madrasah dapat dilihat dari beberapa hal diantaranya: Tercapainya rata-rata ujian nasional peserta didik setiap tahun meningkat lebih baik dari hari sebelumnya yang telah ditetapkan, seperti perolehan nilai akhir yang memuaskan. Selain itu juga pada aspek kognitif, afektif dan psikomotorik dapat mendapat nilai yang di tujukan, sehingga adanya perubahan perilaku peserta didik yang sesuai dengan spiritual keagamaan, pengendalian diri, kepribadian, kecerdasan, akhlak mulia, serta ketrampilan yang dibutuhkan dirinya, masyarakat, bangsa dan negara.

Organisasi pendidikan sudah menjadi hal yang mendasar pembelajaran yang menjadi target pencapaian. Untuk mencapai target yang ditentukan maka dari itu tentulah adanya serangkaian proses yakni: perencanaan pembelajaran yang memberikan bobot pararel pendekatan pembelajaran, subtansi materi dan evaluasi yang berimbang. Hal tersebut haruslah terstruktur dengan jelas dan rapi karena merupakan prinsip manajemen dalam ajaran islam, Sebagaiama Rasulallah SAW bersabda :

"Sesungguhnya Allah sangat mencintai orang yang jika melakukan sesuatu pekerjaan, dilakukan secara itqan (tepat, terarah, jelas dan tuntas)." (HR Thabrani)

Arah pekerjaan yang jelas, landasan yang mantap, dan cara-cara mendapatkannya yang transparan merupakan amal perbuatan yang dicintai Allah SWT. Sebenarnya manajemen dalam arti mengatur segala sesuatu agar dilakukan dengan baik, tepat, dan tuntas merupakan hal yang disyariatkan dalam ajaran Islam (Didin, 2003). 
Oleh karena itu, peneliti sangat tertarik membahas tentang srategi guru, karena disitulah ujung tombak agar supaya melahirkan lulusan yang bermutu. Strategi guru madrasah harus diperbarui secara berkala secara terus menerus, dalam rangka memperoleh masukan untuk evaluasi dan review dalam penyempurnaan mutu lulusan (Buyung, 2016). Madrasah yang telah diteliti ini menjadi rujukan tempat belajar pilihan yang ideal di sekitar karesidenan Kediri, yaitu Blitar, Tulungagung, dan Nganjuk. Persepsi masyarakat menunjukkan tingkat kepercayaan yang tinggi sebagai lembaga yang berprestasi. Hal ini telah ditunjukkan kemampuan para guru menciptakan pembelajaran analog. Pembelajaran ini adalah mengutamakan belajar yang bermakna di setiap materi yang mempunyai ciri abstrak dan konsep, membutukan komparasi antar materi agar bermakna kepada peserta didik sehingga pembelajarannya berkesan dan membekas. Kedudukan guru madrasah tidak sebatas memindahkan pengetahun ke peserta didik, namun menanamkan nilainilai dan memberikan keteladan akhlah yang baik barang tentu tidak sekedar guru mengusai teknologi 4.0., namun mengajarkan nilai-nilai yang dapat membekali diri agar tidak tereduksi oleh pesatnya teknologi digital, kadangkala dapat mendegradasi derajat kemanusiaan dan integritas.

MAN 1 Kota Kediri, menurut persepsi masyarakat lebih unggul dalam bidang keterampilan, karena madrasah ini sudah ditetapkan sebagai salah satu dari beberapa MAN model di Jawa Timur, pada program intrakurikuler khusus menitik beratkan dalam penguasaan ketrampilan hidup (life skill) seperti ketrampilan otomotif motor dan mobil, multimedia, kriya tekstil, elektro, tata boga, elektro dan tata rias, akan tetapi tidak mengesampingkan sebagai MAN bercirikan keagamaan. Salah Satu keunggulan dari MAN 1 Kota Kediri adalah kurikulum pendidikan Islam yang berbasis keterampilan yang telah tersruktur dengan baik, karena madrasah memiliki tim penyusun kurikulum bidang keterampilan. Selain itu, MAN 1 Kota Kediri merupakan MAN acuan di Jawa Timur yang memiliki keterampilan unggul, karena sejak awal keterampilan di MAN 1 Kota Kediri telah dimasukkan pada intrakulikuler.

Madrasah ini mampu menghasilkan benih-benih prestasi di Kota Kediri sampai Nasional. MAN 1 Kota Kediri memberikan terwujudnya lulusan madrasah yang "cerdas, akhlakul karimah, nasionalis, terampil dan inovatif dilandasi keimanan"; yang disingkat "CANTIK". Yakni, cerdas yang mempunyai arti memiliki kompetensi dalam IPTEK sehingga mampu meningkatkan lulusan dalam ujian nasional (UN) dan memiliki daya saing dalam memasuki perguruan tinggi negeri favorit (SPMB). Akhlakul Karimah, Memiliki sikap dan kepribadian yang santun. Nasionalis, memiliki wawasan kebangsaan. Terampil, Memiliki ketrampilan vokasional sebagai bekal kembali ke masyarakat. Inovatif , Memiliki kreatifitas dan inovasi yang tinggi. Keimanan, Menjadikan ajaran dan nilai-nilai Islam sebagai landasan pola berpikir, bersikap, dan bertingkah laku dalam kehidupan sehari-hari. Lulusan MAN 1 Kota Kediri pada tahun 2017 yang masuk ke perguruan tinggi 257 lewat jalur SNMPTN, SPAN-PTKIN, SBMPTN, UM-PTKIN, MANDIRI dari 383 siswa kelas 12.

Selanjutnya, MAN 2 Kota Kediri merupakan madrasah yang unggulan dalam bidang ilmu pengetahuan dan ilmu tehnologi. Terbukti telah memenangkan beberapa lomba di tingkat kabupaten, propinsi sampai tingkat nasional. MAN 2 Kota Kediri merupakan salah satu lembaga pendidikan yang bercirikan Islam dan lebih menekankan pada aspek akademik, dalam menghadapi perkembangan dan tantangan masa depan. MAN 2 Kota Kediri kediri juga disebut sebagai madrasah riset karena pernah terpilih menjadi salah satu dari 12 madrasah riset oleh kementerian agama pusat dan menerima penghargaaan sebagai nominasi penerima madrasah award 2013.

Madrasah ini juga menjadi madrasah favorit sebagian besar alumninya diterima di Perguruan Tinggi Negeri maupun swasta yang tersebar di Pulau Jawa pada setiap tahunnya, Adapun untuk tahun 2017 yang lalu, berdasarkan data sementara, sebanyak 252 dari 397 siswa (63 \%) diterima di perguruan tinggi negeri maupun swasta di Pulau Jawa. Sedangkan untuk tahun 2018, sebanyak 402 dan 85\% masuk perguruan tinggi negeri maupun swasta. Siswanya pernah menjadi salah satu dari dua wakil Indonesia untuk mengikuti lomba penelitian regional SEAMEO (South East Asia Mathematic Education Organitation) di Penang Malaysia pada tahun 2008, finalis Inovative Project Hemisphere Foundation 2014 di Singapura, selama 3 tahun berturut-turut $(2009,2010,2011)$ selalu mendapatkan penghargaan dari Wali Kota sebagai madrasah ter-green and clean di wilayah Kota Kediri, pada tahun 2018 menangkan juara 1 nasyid tingkat nasional yang diadakan oleh KEMENAG dan bekerjasama dengan Metro tv, serta masih banyak prestasi yang lainnya. 


\section{HASIL DAN PEMBAHASAN}

\section{A. Perencanaan Strategi Guru Madrasah dalam Meningkatkan Mutu Lulusan.}

Menurut Alahsanawi (Hamdan, 2013) menyatakan perencanaan mutu sangat penting dalam mencapai tujuan madrasah, salah satu yang terpenting adalah standar, pentingnya budaya mutu, visi, nilai-nilai dan filosofi dalam mewujudkan perencanaan dan misi dalam mewujudkan perencanaan melalui implementasi di madrasahnya.

Perencananaan tersebut juga sesuai dengan ayat Al Qur'an surat Al-Hasyr Ayat:

"Hai orang-orang yang beriman, bertakwalah kepada Allah dan hendaklah Setiap diri memperhatikan apa yang telah diperbuatnya untuk hari esok (akhirat); dan bertakwalah kepada Allah, Sesungguhnya Allah Maha mengetahui apa yang kamu kerjakan." (QS. Al Hasyr 59:18)

Ayat tersebut menjelaskan tentang perintah kepada orang-orang yang beriman untuk bertaqwa kepada Allah SWT dan memperhatikan (mempersiapkan dengan baik) apa yang akan diperbuatnya untuk hari esok. Untuk meningkatkan mutu pendidikan maka guru madrasah/madrasah bersama seluruh stakeholders perlu merumuskan perencanaan pengembangan dan target pencapaian prestasi (mutu) madrasah dalam bentuk konsep perencanaan madrasah.

Berdasarkan hasil temuan penelitian menyatakan bahwa konsep perencanaan pembelajaran dapat membuahkan mutu lulusan diantara kedua madrasah tersebut. Ada persamaan dalam cara menyusun konsep perencanaan, akan tetapi dalam konteknya sangat berbeda. Diantara persamaan sebagai berikut:

\section{Membuat Teamwork dan Memilih Model Pembelajaran di Madrasah.}

Pengembangan pembelajaran sebaiknya menggunakan pendekatan berpusat peserta didik. Peserta didik sebagai subyek pembelajaran yang secara aktif, yaitu mengembangkan minat dan potensi yang dimilikinya. Siswa diharapkan lebih aktif belajar karena tersedianya sumber-sumber rujukan yang dapat diakses secara daring dan guru tentunya menguasai kompetisi pedagogi IT agar dapat merumuskan masalah dan memecahkannya. Disini guru madrasah bersama teamwork kepala madrasah mengidentifikasi dan merumuskan hal yang menjadi skala prioritas yang harus dipenuhi dalam meningkatkan mutu. Tujuan dan sasaran pendidikan harus dirumuskan dengan baik dan terukur karena program-progam dan kebutuhan-kebutuhan madrasah. Seorang guru harus mampu menterjemahkan tercapainya visi, misi dan tujuan madrasah.

MAN 1 Kota Kediri merencanakan kebutuhan sesuai visinya penyelenggara ketrampilan. MAN 2 lebih mengkonsep perencanan 8 SNP dan mendatangkan tenaga ahli sebagai pengarah perencanaan. Teamwork dari MAN 1 Kota Kediri adalah membentuk kepanitiaan dan penanggung jawab setiap program yang direncanakan. Sedangkan MAN 2 Kota Kediri teamwork adalah berdasarkan struktur madrasah berdasarkan program yang dibuat oleh kepala madrasah, seluruh waka, guru dan TU yang dipilih berdasarkan jabatanya masing-masing.

MAN 1 dan MAN 2 Kota Kediri dalam menyusun perencanaan sama-sama membuat teamwork yang terdiri dari kepala madrasah, wakil kepala madrasah, guru-guru, TU dan Staf. Hal ini sesuai dengan teori Chesswas, Disini kepala madrasah bersama teamwork mengidentifikasi dan merumuskan hal yang menjadi skala prioritas yang harus dipenuhi dalam meningkatkan mutu. Tujuan dan sasaran pendidikan harus dirumuskan dengan baik dan terukur karena program-progam dan kebutuhan-kebutuhan dalam madrasah harus mendukung dan mendorong tercapainya visi, misi dan tujuan madrasah.

\section{Mengundang Narasumber Bidang Pembelajaran Berbasis IT.}

MAN 1 dan MAN 2 Kota Kediri dalam merencanakan program selama setahun kedepan mengundang narasumber di bidangnya. MAN 1 Kota Kediri untuk mempersiapkan program yang berkaitan dengan keterampilan guru dalam mendesain pembelajaran kontekstual maka di awal akan diselenggarakan program tersebut maka guru mengusulkan kepada kepala madrasah mengundang narasumber yang mempunyai keahlian pembelajaran berbasis IT untuk membekali kompetensi pedagogi yang bersifat konvensional para guru di MAN 1 Kota Kediri ke pembelajaran bauran, yaitu memadukan tatap muka dan e-learning. 
Sedangkan MAN 2 Kota Kediri juga mengundang guru yang mempunyai prestasi menjadi narasumber untuk memberi inspirasi para guru berkaitan dengan program-program unggulan yang perlu dikembangkan di madrasah.

Mengundang narasumber seperti teori yang dikemukakan oleh Edward Sallis, (Edward Sallis,2012) konsultan bisa digunakan untuk: pertama, konsultan dapat memberikan nasihat awal dan memberikan petunjuk serta merubah tim manajemen senior. Kedua, melatih terampil dan meningkatkan kesadaran para staf. Kedua, menjadi kritikus hebat terkait kebijakan-kebijakan institusi. Keempat, konsultan bermanfaat dalam menyusun audit formal, penilaian dan evaluasi.

\section{Merancang Pembelajaran yang Kolaborasi dengan Orang Lain.}

Pembelajaran dirumuskan mencerminkan persiapan dan hal-hal yang akan dilakukan guru dan peserta didik. Melalui tujuan yang telah ditentukan, dapat digambarkan hal-hal apa yang akan segera diwujudkan oleh di madrasah. Perencanaan pembelajaran arahnya merujuk pada visi dan misi madrasah, Seperti teori yang dikemukakan oleh J. David Hunger \& Thomas L. Wheelen yaitu Visi dan misi madrasah disusun untuk membedakan sebuah organisasi satu dengan organisasi lainya dan mengidentifikasi jangkauan operasi organisasi dalam mewujudkan 'produk' yang ditawarkan dan 'pasar' yang melayani. ( J. David, 2003)

MAN 1 dan MAN 2 Kota Kediri merancang perencanaan jangka pendek, dan jangka pangjang. Yaitu diantara 2 kasus perencanaan jangka pendek adalah sama-sama membuat RPP wajib bagi setiap guru, sedangkan jangka panjang MAN 1 lebih menargetkan lulusan yang memiliki ketrampilan dan bisa melanjutkan bidang yang di minati diperguruan tinggi. Sedangkan MAN 2 lebih fokus mencetak lulusan yang berkompeten dan dapat berkolaborasi dengan siapa saja agar menginspirasi warga madrasah lebih dari hari sebelumnya.

Future oriented adalah perencanaan yang mengarah kepada masa depan, sama-sama berorientasi ke masa depan akan tetapi perbedaanya adalah MAN 1 Kota kediri lebih ke penguatan skill atau ketrampilan dan akademik. Sedangkan MAN 2 Kota Kediri juga future oriented tapi di lebih ke penguatan akademik, ada ma'had dan siswa bisa melanjutkan belajar ke jenjang yang lebih tinggi.

Menurut Poole, Cooney, Nurmi dan Green menjelaskan bahwa setiap keputusan yang dibuat mulai memperhatikan masa depan seperti pekerjaan di masa depan, pendidikan di masa depan, dan membangun keluarga. Perhatian dan harapan yang terbentuk tentang masa depan, serta perencanaan untuk mewujudkannya, inilah yang dikenal dengan orientasi masa depan (OMD). ( Raffaelli, 2005)

Hal ini sejalan dengan teori Tjijono dan Diana mengemukakan untuk melaksanakan perbaikan secara terus menerus ada lima aktivitas pokok yang harus di jalankan step by step. 1). Komunikasi, 2). Memperbaiki masalah yang nyata dan jelas. Yaitu dengan pendekatan ilmiah siklus PDCA (plan, do, check, act) sangat perlu digunkan untuk perbaikan mutu secara terus-menerus. 3). Memandang kehulu, berarti mencari penyebab suatu masalah, bukan gejalanya. Alat yang bisa digunakan untuk memisahkan antara penyebab dan gejala adalah diagram sebab-akibat (diagram tulang ikan). 4). Mendokumentasikan kemajuan dan masalah. 5). Memantau perubahan.

Gambar

Konsep Perencanaan Peningkatan Mutu Lulusan MAN 1 dan MAN 2 Kota Kediri

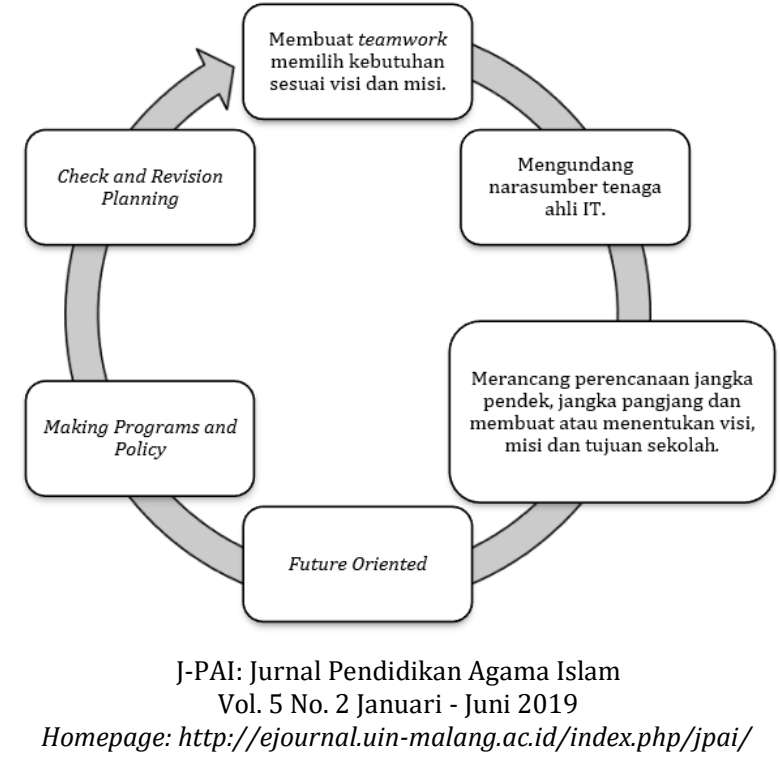




\section{B. Langkah-Langkah Implementasi Peningkatan Mutu Lulusan}

Menurut Ikezawa, implementasi manajemen diartikan sebagai perpaduan semua fungsi dari perusahan ke dalam falsafat holistic yang dibangun berdasarkan konsep kualitas, teamwork, produktivitas dan pengertian serta kepuasan pelanggan. (Tatsuo Ikezawa,1993) Implementasi manajemen mutu pendidikan adalah proses mengkoordinasikan berbagai kegiatan kerja agar diselesaikan secara efektif dan efesien dengan orientasi pada kualitas, kemudian dikatakanya bahwa implementasi adalah proses melaksanakan program yang sudah direncanakannya. (P.Stephen, 1999))

Di dalam Islam, upaya menggerakan dan membangkitkan semangat bekerja guna mencapai tujuan yang diinginkan merupakan hal yang sangat penting. Sebagaimana Allah SWT berfirman dalam Al-Qur'an Surat At Taubah Ayat 105

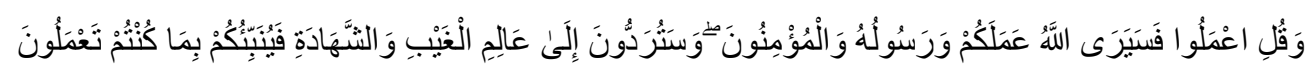

Dan Katakanlah: "Bekerjalah kamu, Maka Allah dan Rasul-Nya serta orang-orang mukmin akan melihat pekerjaanmu itu, dan kamu akan dikembalikan kepada (Allah) yang mengetahui akan yang ghaib dan yang nyata, lalu diberitakan-Nya kepada kamu apa yang telah kamu kerjakan." (QS.At Taubah 9:105)

M. Quraish Shihab dalam tafsirnya menerangkan bahwa, kata وقل اعملو diartikan katakanlah bekerjalah kamu karena Allah semata dengan aneka amal shaleh dan bermanfaat. Dari ayat di atas, menjelaskan perlunya semangat dan motivasi dalam bekerja yang dibangun atas dasar keikhlasan semata-mata mengharapkan keridho'an dan keberkahan Allah SWT atas upaya yang telah dikerjakan. Dalam upaya meningkatkan mutu pendidikan, maka pimpinan madrasah/madrasah bersama-sama dengan guru dituntut untuk senantiasa membangkitkan motivasi (al-baits) dan semangat dalam belajar dan membelajarkan peserta didik di lingkungan satuan pendidikan masingmasing.

Untuk mengimplentasikan manajemen peningkatan mutu lulusan perlu strategi untuk diterapkan oleh para guru. yaitu beberapa startegi yang berdasarkan temuan penelitian sebagai berikut:

\section{Komitmen Para Guru Madrasah.}

Langkah pertama yang dibangun adalah komitmen para guru madrasah. Guru Madrasah MAN 1 dan MAN 2 Kota Kediri dalam mengimplementasikan perencanaan madrasah dapat mencapai mutu lulusan yang diharapkan. Sudah menjadi tugas seorang guru madrasah menanamkan nilai-nilai dan keteladanan di lingkungan warga madrasah, TU dan staf beserta sumberdaya manusia yang ada di madrasah. Dengan adanya komitmen maka seluruh sumberdaya manusia yang ada di madrasah mampu berjuang secara optimal dalam melaksanakan tugasnya sehingga mampu mewujudkan lulusan yang bermutu. Menurut advard Sallis Komitmen harus dimiliki oleh guru madrasah yang mempunyai karakteristik sebagai leader dan manajer, karena guru madrasah sebagai kunci dari keberhasilan madrasah.

\section{Jejaring sosial para guru madrasah.}

MAN 1 dan MAN 2 Kota Kediri dalam mengimplementasikan perencanaan membutuhkan koordinasi diantara seluruh elemen individu yang ada pada madrasah, kususnya wakil kepala madrasah, guru dan staf. Guru madrasah tidak mungkin bekerja sendiri tanpa adanya sebuah tim yang solid dalam mewujudkan program yang telah dirumuskan, guru mempunyai wilayah di intrernal pembelajaran, kepala madrasah mempunyai tanggung jawab lembaganya. Tentu saja guru madrasah sebagai leader dan manajer puncak bisa bisa menempatkan orang-orang yang tepat pada struktur organisasi akan membuka peluang suksesnya program atau kegiatan. Pembentukan struktur penanggung jawab program juga akan mempermudah mengontrol pada tahap evaluasi. 


\section{Komunikasi antar guru madrasah}

Pentingnya sebuah komunikasi dalam sebuah organisasi untuk menyampaikan informasi secara cepat, tepat dan akurat. Komunikasi bertujuan untuk mengkoordinasikan tugas dan fungsi seluruh elemen sumber daya manusia untuk menggerakan mutu lulusan. Jika komunikasi berjalan dengan baik maka sebuah teamwork akan lebih mudah mencari jalan keluar atau terobosan masalah jika terjadi kesalah pahaman atau ada masalah yang perlu dipecahkan.

\section{Pelaksanaan Peningkatan kualitas guru mata pelajaran}

Selaras dengan teori menurut muhaimin, ada kaitan yang erat antara profesionalisme dan mutu produk kerja seseorang. Keberhasilan atau kegagalan guru dalam meningkatkan profesionalisme akan dapat dirasakan masyarakat melalui profil para lulusannya. Selama masyarakat mengeluh tentang mutu hasil pendidikan, maka guru mempunyai kewajiban sosial untuk meningkatkan mutu hasil pendidikan sebagai wujud profesionalisme dan etos kerjanya. (Muhaimin, 2003) Dapat disimpulkan, pemberian kesempatan untuk meningkatkan kualitas sumber daya manusia yang dimiliki oleh sebuah organisasi berasal dari pemimpin. Keberhasilan guru madrasah salah satunya ditentukan dalam mengembangkan model pembelajaran yang berdampak pada mutu lulusan. Di antaranya berikut ini.

\section{Peningkatan mutu pembelajaran}

Pembelajaran mempunyai beberapa komponen, yaitu komponen: tujuan pengajaran, bahan ajaran, metode belajar mengajar, media, dan evaluasai pengajaran. Meningkatkan efesiensi dan efektivitas proses belajar mengajar, proses pembelajaran selalu dipantau dalam rangka melihat konsistensi antara desain yang telah direncanakan dengan pelaksanaan pembelajaran. Dengan demikian ketidak sesuaian antara desain dengan implementasi dapat dihindarkan. Disamping itu, guru maupun siswa selalu termotivasi untuk melaksanakan pembelajaran yang efektif dan efesien, karena adanya dukungan kondisi positif yang diciptakan dalam kegiatan pengelolaan kurikulum.

\section{Peningkatan mutu pelayanan dan pengembangan kurikulum}

Hal ini sesuai dengan teori menurut Kotler definisi pelayanan adalah setiap tindakan atau kegiatan yang dapat ditawarkan oleh suatu pihak kepada pihak lain, yang pada dasarnya tidak berwujud dan tidak mengakibatkan kepemilikan apapun. Produksinya dapat dikaitkan atau tidak dikaitkan pada satu produk fisik. Pelayanan merupakan perilaku produsen dalam rangka memenuhi kebutuhan dan keinginan konsumen demi tercapainya kepuasan pada konsumen itu sendiri. Kotler juga mengatakan bahwa perilaku tersebut dapat terjadi pada saat, sebelum dan sesudah terjadinya transaksi. Pada umumnya pelayanan yang bertaraf tinggi akan menghasilkan kepuasan yang tinggi serta pembelian ulang yang lebih sering.

Kurikulum yang digunakan oleh MAN 1 dan MAN 2 kota Kediri menggunakan kurikulum 2013, akan tetapi ada sedikit perebedaan pada MAN 1 Kota Kediri, yaitu ada rekayasa kurikulum pada MAN 1 Kota Kediri karena sebagai madrasah penyelenggara ketrampilan maka ada modifikasi mengenai kurikulum yang diterapkan dengan tidak mengubah subtansi dari garis besar kurikulum. Yaitu memasukan program ketrampilan di jam formal selama satu minggu 4 jam pertemuan. Sedangkan untuk MAN 2 Kota Kediri kurikulum juga sama menggunakan kurikulum 2013, akan tetapi ada tambahan yang yaitu kurikulum ma'had karena MAN 2 Kota Kediri memiliki ma'had yang ada di madrasah. Selain belajar di madrasah siswa juga bisa belajar di ma'had MAN 2 Kota Kediri.

\section{Peningkatan prestasi Akademik dan non Akademik}

Ada strategi kusus yang diterapkan oleh guru madrasah dalam meningkatkan prestasi akademik dan non akademik. Dengan diterapkan open managemen dalam mengelola madrasah maka seluruh warga madrasah memiliki rasa memiliki, kepercayaan dan ingin berkembang bersama. Oleh karena itu open managemen yang diterapkan di MAN 2 Kota Kediri memiliki kekuatan tersendiri untuk berprestasi.

Peningkatan prestasi akademik dan non akademik yang dilakukan oleh MAN 1 dan MAN 2 Kota Kediri adalah sebagai berikut; pertama, peningkatan prestasi akademik.Peserta didik yang 
mengikuti kegiatan belajar mengajar mendapatkan nilai dari setiap proses pembelajaran yang diikuti. Kegiatan belajar mengajar di madrasah, akan menghasilkan nilai atau tolak ukur prestasi yang didapatkan oleh setiap siswa. Nilai yang dihasilkan oleh setiap siswa dibagi menjadi dua yaitu dari bidang akademik dan non-akademik. Kedua, peningkatan prestasi non akademik. Pogram kesiswaan yang dikembangkan oleh MAN 1 dan MAN 2 Kota Kediri dalam mengembangkan potensi siswa diantaranya pembinaan dalam kegiatan OSIS dan ekstrakurikuler, mulai dari bidang olahraga keterampilan, wawasan kebangsaan, sampai pembinaan dalam bidang agama. Pembinaan OSIS dan ekstrakurikuler dilakukan untuk mempersiapkan siswa menjadi kader penerus bangsa dan memberikan fasilitas dalam mengembangkan potensi siswa sesuai dengan minat dan bakatnya sekaligus keterampilan-keterampilan sebagai bekal dalam melanjutkan pendidikan yang lebih tinggi dan kehidupan bermasyarakat.

Standarisasi sarana dan prasarana madrasah sangat diharuskan dalam suatu. Pada proses pendidikan dan pembelajaran memerlukan fasilitas pendukung yang sesuai dengan kebutuhan masing-masing lembaga pendidikan. Program dalam bidang sarana dan prasarana dirumuskan agar sarana dan prasarana memiliki nilai guna yang maksimal. Organisasi pendidikan agar dapat meningkatkan mutu lulusan.

Program-program yang disusun untuk meningkatkan mutu lulusan perlu mendapat dukungan dari semua pihak, baik itu pihak internal maupun eksternal. Disinilah salah satu peran bidang hubungan masyarakat (humas), yang menjadi jembatan antara pihak madrasah dengan pihak luar madrasah yang berkepentingan. Secara garis besar, keberadaan humas dalam sebuah organisasi sangat diperlukan untuk menjalin komunikasi dengan para stakeholder dan untuk mengkomunikasikan visi, misi, tujuan, program madrasah kepada publik.

Program kesiswaan adalah sasaran utama dalam meningkatkan mutu lulusan. kualitas madrasah akan dicerminkan dengan kualitas lulusannya dalam menguasai kemampuan afektif, kognitif dan psikomotorik. Program kesiswaan dirumuskan untuk mencetak siswa yang agar menjadi lebih disiplin, berakhlakhul karimah, bertanggung jawab, mampu menguasai tehnologi, mempunyai ketrampilan dan bisa berkontribusi di masyarakat serta bisa melanjutkan studi di perguruan tinggi.

Program MAN 1 dan MAN 2 Kota Kediri dalam membina siswa ada kesamaan yaitu, pertama, bapak ibu guru memberi suri tauladan yang suri tauladan yang baik/uswatun hasanah. Kedua, membentuk tim tatib. Ketiga, bimbingan berkelanjutan oleh BK dan bimbingan masuk keperguruan tinggi.

Evaluasi diri secara objektif terhadap kondisi madrasah yang sebenarnya merupakan langkah awal yang harus ditempuh sebelum membuat perencanaan mutu lulusan di lembaganya. Evaluasi internal berfungsi melihat peluang dan tantangan yang dihadapi madrasah dalam meningkatkan mutu lulusan. Guru madrasah harus menterjemahkan kebijakan kepala madrasah kebijakan agar mengimplementasikan agar mutu bisa tercapai dengan baik berdasarkan visi dan misi yang dimiliki oleh madrasah. Intinya harus ada kebijakan dalam menghadapi peluang dan tantangan dalam meningkatkan mutu lulusan.

Evaluasi yang dilakukan oleh MAN 1 dan MAN 2 Kota Kediri, tidak untuk mengetahui akhir kegiatan semata, akan tetapi sebagai bahan pertimbangan dalam memperbaiki program kedepannya. Evaluasi program peningkatan mutu dari kedua madrasah ini mirip dengan model CIPP. CIPP merupakan model penilaian program yang dikembangkan oleh Daniel L. Stufflebeam, model ini terdiri dari (Rosady, 2005):

1) penilaian konteks evaluasi (context evaluation). MAN 1 dan dan MAN 2 Kota Kediri melakukan monitoring dan pengawasan terhadap program yang direncanakan. Hal ini dilakukan untuk mengetahui potensi real madrasah dan tetap dalam harapan stakeholders. selain itu madrasah dapat mengetahui program yang dapat dilanjutkan dalam priode berikutnya.

2) Penilaian tentang masukan (input evaluation). MAN 1 dan dan MAN 2 Kota Kediri dalam mengevaluasi program peningkatan mutu pendidikan dengan melihat potensi yang dimilikinya, dengan harapan antara program yang direncanakan dapat sesuai dengan kondisi madrasah. Dalam hal ini madrasah mencari informasi dari beberapa pengguna madrasah, seperti dewan guru, staf, dewan yayasan dan komite madrasah dengan menyelenggarakan musyawarah. 3) Penilaian tentang proses (process evaluation). 4) Penilain ini dengan menggali informasi dan mengumpulkan data terkait dengan faktor-faktor pendukung dan penghambat terealisasinya program madrasah. Proses

J-PAI: Jurnal Pendidikan Agama Islam

Vol. 5 No. 2 Januari - Juni 2019

Homepage: http://ejournal.uin-malang.ac.id/index.php/jpai/ 
evaluasi ini berjangka ada evaluasi mingguan, bulanan, semester dan tahunan yang selanjutnya dapat dijadikan bahan pertimbangan dalam menjalankan program di periode berikutnya. Selain itu kepala madrasah juga melakukan monitoring pada waktu proses pelaksanaan program, untuk mengecek sesuai atau tidak dengan perencanaan sebelumnya. 5) Penilaian tentang produk/hasil (product evaluation). 6) Product evaluation bisa disebut juga Laporan evaluasi berupa laporan tertulis. Selain itu, pada tahap ini berupa penilain ini dikhususkan terhadap hasil akhir dari program yang dilaksanakan. seperti keberhasilan prestasi yang diraih dan lulusan yang dapat diterima di perguruan tinggi.

\section{Implikasi peningkatan mutu lulusan di MAN 1 dan MAN 2 Kota Kediri}

Implikasi peningkatan mutu lulusan di MAN 1 dan MAN 2 Kota Kediri memberi dampak yang positif kepada internal dan eksternal madrasah. antara lain dampak dari peningkatan mutu lulusan antara lain adalah: 1) Implikasi ke madrasah. Implikasi ke madrasah yaitu meningkatnya prestasi madrasah, madrasah lebih mudah Promosi dan Meningkatnya kinerja guru. Meningkatknya prestasi madrasah maksutnya adalah jika mutu madrasah berimplikasi kemadrasah maka madrasah mempunyai peringkat teratas untuk mencetak lulusan bermutu. Madrasah lebih mudah promosi adalah dengan adanya peningkatan mutu lulusan maka madrasah lebih percaya diri mempromosikan kepada perguruan tinggi, perusahaan dan masyarakat karena lulusan sudah mempunyai keunggulan tersendiri. Meningkatnya kinerja guru adalah dengan adanya program peningkatan mutu maka guru akan lebih disiplin, kreatif dan inovatif dalam menjalankan proses belajar mengajar, jika proses belajar mengajar itu baik, maka output juga akan berkualitas. 2) Implikasi ke siswa. Implikasi ke siswa yang ada di MAN 1 dan MAN 2 Kota Kediri adalah kompetensi lulusan semakin baik, siswa lebih siap terjun ke masyarakat atau dunia kerja, masuk perguruan tinggi dan siswa lebih terampil dan mempunyai skill.

Kompetensi lulusan semakin baik, maksutnya siswa menguasai standartkompetensi kelulusan madrasah yang harus dikuasai oleh siswa baik dari aspek afektif, kognitif dan psikomotorik. Siswa lebih siap terjun ke masyarakat atau dunia kerja artinya MAN 1 Kota Kediri yang merancang untuk mencetak lulusan yang unggul dan terampil tentu harapanya jika lulus bisa berkontribusi di masyarakat untuk membuka usaha dan bisa masuk dunia kerja karena di madrasah sudah belajar tentang bidang keahlian seperti SMK. MAN 2 Kota kediri dari awal kepala madrasah sudah menargetkan jika lulusan MAN 2 kota Kediri merupaka calon pelajar yang akan masuk di perguruan tinggi. Maka sesuai target dan tujuan dari madrasah dan kepala madrasah tahun 2018 banyak lulusan masuk keperguruan tinggi negeri maupun swasta, yaitu sekitar $85 \%$ dari jumlah kelulusan tahun tersebut.

Dampak dari peningkatan mutu lulusan di MAN 1 dan MAN 2 Kota Kediri juga kemasyarakat luas juga. Yaitu; masyarakat semakin percaya guru madrasah dan masyarakat bisa memilih madrasah yang cocok untuk anaknya. Pertama, masyarakat semakin percaya pada madrasah maksutnya adalah kepercayaan orang tua dan masyarakat untuk menyekolahkan anaknya di madrasah MAN 1 dan MAN 2 Kota Kediri semakin banyak, karena madrasah sendiri menjaga kepercayaan kepada orang tua siswa. Kedua, Masyarakat bisa memilih madrasah yang cocok utuk anak-anaknya sesuai dengan keinginan, bakat dan minat anak-anaknya.

Adapun ada perbedaan implikasi antara MAN 1 dan MAN 2 Kota Kediri, perbedaannya sebagai berikut: Implikasi ke madrasah di MAN 1 Kota Kediri karena madrasah sebagai penyelenggara ketrampilan maka implikasinya adalah lebih mudah mencari mitra kerja dan branding image. Pertama, mudah mencari mitra kerja maksutnya adalah MAN 1 Kota Kediri yang bercirikan madrasah ketrampilan maka dalam menjalin relasi seperti maggang di perusahaan, pelatihan di Balai Latihan Kerja Kediri lebih mudah dan juga ketika sudah lulus siswa, jika siswa memppunyai keahlian kusus maka lulusan lebih mudah diterima diperusahaan atau bisa membuka usaha sendiri lebih mandiri. Kedua, branding image maksutnya adalah antara kedua madrasah tersebut mempunyai branding image sendiri-sendiri. MAN 1 Kota Kediri lebih terkenal dengan madrasah ketrampilan, sedangkan MAN 2 Kota Kediri lebih terkenal dengan keunggulan akademiknya. 


\section{KESIMPULAN}

Perencanaan strategi guru madrasah dalam meningkatkan mutu lulusan di MAN 1 dan MAN 2 Kota Kediri, adalah: a) Membuat teamwork memilih kebutuhan sesuai visi dan misi, b) Mengundang konsultan eksternal/tenaga ahli, c) Merancang perencanaan jangka pendek, jangka pangjang susuai visi, misi dan tujuan madrasah. d) Orientasi Masa depan/ Future oriented, e) Membuat program dan menentukan kebijakan/ Making programs and policy, f) Mengecek ulang dan merevisi perencanaan/ check and revision planning. Hal ini sesuai dengan teori konsep perencanaan yang dikemukakan oleh Chesswas. Dalam setiap lembaga untuk mencapai mutu harus ada perencanaan secara jelas dan terarah.

Langkah-langkah implementasi peningkatan mutu lulusan di MAN 1 dan MAN 2 Kota Kediri sebagai berikut: a) Komitmen, b) Membentuk tim/ teamwork, c) Komunikasi, d) Implementasi program-prgram, diantaranya yaitu: 1) Peningkatan kualitas guru mata pelajaran dengan cara up grading, diklat dan studi banding., 2) Peningkatan kualitas pelayanan dan kurikulum, 3) peningkatan mutu pembelajaran yaitu memaksimalkan proses belajar dan mengajar dengan mengupdate metode pembelajaran terbaru, 4) peningkatan mutu akademik dan non akademik, 5) Peningkatan sarana dan prasarana, 6) program humas mengembangkan program internal dan eksternal, 7) program kesiswaan yaitu menanamkan akhlakul karimah dan program pertukaran pelajar antar negara dan . e) evaluasi, ada 4 macam yaitu, 1) penilaian konteks evaluasi, 2) penilaian tentang masukan, 3) proses evaluasi, 4) penilaian tentang lulusan atau hasil.

Implikasi strategi guru madrasah dalam meningkatkan mutu lulusan di MAN 1 dan MAN 2 Kota Kediri sebagai berikut: a) Implikasi madrasah adalah meningkatnya prestasi madrasah, madrasah lebih mudah promosi, meningkatnya kinerja guru selain itu menjadikan madrsah mempunyai keunikan tersendiri, yaitu di MAN 1 memiliki keunggulan di bidang ketrampilan sedangkan di MAN 2 Kota Kediri memiliki keunggulan di bidang akademik dan riset ilmiah . b) Implikasi ke siswa adalah kompetensi lulusan semakin baik, siswa lebih siap terjun ke masyarakat, dunia kerja dan perguruan tinggi serta siswa lebih terampil dan mempunyai skill. c) Implikasi eksternal/ Masyarakat adalah masyarakat semakin percaya kepada madrasah dan masyarakat bisa memilih madrasah yang sesuai minat dan bakat untuk anaknya.

\section{DAFTAR PUSTAKA}

Arsyad, Muhammad, Mencermati Standar Kepala Sekolah, mailto:mma-mars@yahoo.co.id, diakses tgl 06 Agustus 2018.

Badan Akreditasi Nasional Sekolah/Madrasah, 2017. Perangkat Akreditasi SMA/MA, Menteri Kebudayaan dan Pendidikan Nasional.

Chairul Anwar, Kepala Sekolah dan Peningkatan Mutu Guru, http://www. koranpendidikan.com , diakses tgl 21 Desember 2018.

Depdikbud RI, 1998. Kamus Besar Bahasa Indonesia. Jakarta: Balai Pustaka.

Hambali, Muh., Manajemen Pengembangan Kompetensi Guru PAI,J-MPI., Vol. 1, No. 1, Januari-Juni 2016. http://ejournal.uinmalang.ac.id/index.php/jmpi/article/view/3229/5187

Hamdan, Ahmed Dkk, 2013. The Impact of Planning on the Quality of Educational Programs at AlBalqa' Applied University. International Journal of Business Administration; Vol. 4, No. 5.

Hanusbeck, Eric A (2005). Why Quality Matters in education. http://edpro.standforedu.Hanushek/admin/pages/files/uploads/FinDef.june05.pdf.(Diaks es 20 Februari 2018)

http://edpro.standforedu.Hanushek/admin/pages/files/uploads/FinDef.june05.pdf.(Diakses Februari 2018)

Hunger, J. David \& Thomas L. Wheelen. 2003. Manajemen Strategis, terj. Julianto Agung S. Cet. 16, Yogyakarta: Andi. 
Ikezawa, Tatsuo, 1993. Effective TQC; How To Make Quality Assurance More Than a Sloga. Tokyo: PHP Institut, INC.

Lampiran Peraturan Mentri Pendidikan Nasional Nomor 13 Tahun 2007 Tanggal 17 April 2007 Tentang Standar Kepala Sekolah/Madrasah

Lestari Handayani, Perbedaan Prestasi Akademik dam Non-Akademik Kelas XI Program Reguler dan Akselerasi di SMA Negeri 4 Malang, Fakultas Ilmu Pendidikan UM 2010, Skripsi tidak diterbitkan

Muhaimin. 2003. Wacana Pengembangan Pendidikan Islam. Yogyakarta: Pustaka Pelajar.

Mulyasa, E, 2011. Manajemen \& Kepemimpinan Kepala Sekolah , Jakarta: Bumi Aksara.

Peraturan Menteri Pendidikan Dan Kebudayaan Republik Indonesia Nomor 4 Tahun 2018, Pasal 19 Ayat 1.

Raffaelli, M, Silvia dan H. Koller. 2005. Future Expectations of Brasilian street Youth. Journal of Adolescence. Diakses dari http://www.msmidia.com/ceprua/artigos/future. pdf pada tanggal 11 juni 2018.

Raffaelli, M, Silvia dan H. Koller. 2005. Future Expectations of Brasilian street Youth. Journal of Adolescence. Diakses dari http://www.msmidia.com/ceprua/artigos/future. pdf pada tanggal 11 juni 2018

Rusalan, Rosady. 2005. Manajemen Public Relations dan Media Komunikasi: Konsep dan Aplikasi. Jakarta: Raja Grafindo Persada.

Sallis, E. 2007. Total Quality Management in Education. Jogjakarta : IRCiSoD.

Spencer, Lyle M, 1993. Competence at Work: Models for Superior Performance, Canada: John wiley \& Son, Inc.

Sri Damayanti, Profesionalisme Kepala Sekolah.http://akhmadsudrajat.wordpress.com

Stephen, P dan Marry Coulter Robbin. 1999. Management six edition. New Jersey: Prentice-Hall, Inc.

Sukron, Buyung, Agustus 2016. Implementasi Manajemen Mutu Terpadu Studi Transformatif Pada Perguruan Tinggi. Stain Jurai Siwo Metro. Jurnal Penelitian, Vol. 10, No. 2. 